\title{
Hangzók és hangzások
}

\author{
Kovács Katalin: Elment a hangom...! \\ Kisgyermekek között éneklők (kisgyermeknevelők, \\ óvodapedagógusok, tanítók) hangképzésének \\ fontossága és Döbrössy János: Fontos-e a szövegejtés \\ éneklés közben?
}

\begin{abstract}
Kovács Katalin ${ }^{1}$ és Döbrössy János ${ }^{2}$
${ }^{1}$ Eötvös Loránd Tudományegyetem Tanitó- és Óvóképzö Kar Ének-zenei Tanszék, ELTE PPK, Neveléstudományi Doktori Iskola
\end{abstract}

${ }^{2}$ Eötvös Loránd Tudományegyetem Tanitó- és Óvóképzö Kar Ének-zenei Tanszék

\begin{abstract}
Absztrakt
Az ELTE TÓK Ének-zenei Tanszékének 2021-es zenepedagógiai konferenciája a Magyar zene és kultúra témáival foglalkozott. Ezen a konferencián hangzott el az alcímekben olvasható két előadás, melyek összefüggéseket rejtenek, s amelyeket e tanulmány kifejt. Mindkét téma a kisgyermeknevelés fontos területét jelenti, az egyetemen folyó képzés szempontjából meghatározó: a helyes hangképzéssel, artikulációval jó mintát mutatni (Kovács Katalin témája), mindezt érthető és anyanyelvünknek megfelelő szövegejtéssel, az eredeti hangzóformálásra, helyes éneklésre irányító gyakorlatokkal létrehozni (Döbrössy János témája). Zenei nevelésünk céljai Kodály Zoltán koncepciójára épülnek. Kodály elképzelésének lényeges eleme, hogy a zene átéléséhez, megértéséhez legközvetlenebbül az éneklés vezet. Zeneoktatásunkban az énekes szemlélet sokkal jobban előtérbe kell, hogy kerüljön. Az éneklés az, ami felszabadít, gazdagít, örömet ad. Az énektechnikai tudás pedig eszközt teremt a zenei feladatok megoldására. Az aktív zenélés, az éneklés, illetve a zenei képességfejlesztés lehetőséget kínál a művészet tartalmi befogadásra, személyiségfejlődésre, zenei fejlődésre.
\end{abstract}

Kulcsszavak: kisgyermekkori nevelés, éneklés, hangképzés, artikuláció, szöveghangsúly

\section{Bevezetés}

„Semmi sem jellemző annyira a nyelvre, mint sajátos hangzása. Olyan ez, mint a virág illata, a bor zamata, a zománc, az opál tüze. Megismerni róla a nyelvet már messziről, mikor a szót még nem is értjük." - mondja Kodály Zoltán a nyelvről 1938-ban (Bónis, 1974, p. 300). 
Művészet és tudomány mély belső egységet alkot. A művészetekben rejlő értékek olyan erkölcsi alapot biztosítanak a felnövekvő nemzedék számára, amelyekre mindenkinek szüksége van a hétköznapokban, azért, hogy az ember kiteljesítse önmagát, esetlegesen a zene iránti vágyát. A művészetoktatás hatékonyságának alapfeltétele a művészileg elkötelezett és jól képzett pedagógusok jelenléte.

Pukánszky és Németh (1996) szerint a társadalom- és nevelésfilozófia területének 1867-1919 közötti időszakában azt látjuk, hogy az 1867-es kiegyezési törvény a pedagógiát és iskoláztatást új alapokra helyezte, lehetőséget teremtett a magyar társadalom polgári fejlődése számára, s - ezzel párhuzamosan - kedvező feltételeket biztosított a magyar iskolaügy korszerüsítésére, tartalmi-szervezeti modernizálására. Eötvös József mint vallás- és kultuszminiszter az egész magyar közoktatás gyökeres átformálását tűzte ki célul, és ebben a többlépcsős folyamatban szerinte abszolút elsőbbséget élvezett a népoktatás ügye.

A népiskoláztatás kérdése mellett Eötvös az óvodáknak is figyelmet szentelt. A kisdedóvást szabályozó törvény 1891-ben lépett életbe (1891, 15 cikkely). Azzal a céllal illesztette be az óvodát a magyar köznevelési rendszerbe, hogy a 3-6 éves gyermekek szüleik távollétében ellátást kapjanak, gondozásban részesüljenek; elősegítse testi, értelmi és erkölcsi fejlődésüket. Óvónőképző intézetbe ettől kezdve csak a polgári iskola vagy a gimnázium négy osztályának elvégzése után jelentkezhettek. Külön érdemes figyelni felvételi feltételeire, hiszen felvételt csak az alábbi követelményeket teljesítő fiatalok nyerhettek: egészséges, ép testalkat, megfelelő zenei hallás, betöltött 14. év.

A kodályi alapelveknek megfelelően a magyarországi zenei nevelés az énekhangra épül. Az emberi hang mindenki számára hozzáférhető hangszer, amely a zenei élménynyújtás és ismeretszerzés alapvető eszköze. Kodály Zoltán az éneklést tartotta az aktív zenélés legtermészetesebb módjának. Számos külföldi és magyar kutatás (Erős, 1993; Welch, 1997; Berkowska \& Dalla Bella, 2009; Turmezeyné \& Balogh, 2009; Janurik \& Józsa, 2013) alátámasztja, hogy az éneklés a zenei fejlődésnek legfontosabb kulcsösszetevője. A hallás fejlesztésében rendkívül nagy jelentőséggel bír az éneklés, amely megalapozza a zenei írás-olvasási képességet, és az erre épülő hangszertanulást. Amikor hangszeren játszunk, zenét hallgatunk vagy egy dallamot elképzelünk, eközben belül is éneklünk, amit a gége mozgató izmainak műszeres vizsgálata is bizonyított (vö. Peretz \& Zatorre, 2005; Altorjay, 2019).

A mủvészeti oktatás és nevelés során a pedagógus feladata azonban nemcsak az ismeret átadására, hanem az alkotásra, a tapasztalás élményének megteremtésére, az érzékenyítésre is kiterjed. Zenéhez való viszonyulásunkat, különböző zenei tevékenységekben való részvételi hajlandóságunkat nagymértékben befolyásolhatja zenei énképünk (musical self-concept), azon elképzeléseink összessége, hogy milyen lehetőségekkel rendelkezünk a zenével összefüggő tevékenységek és a zenei fejlődés terén (Spychiger, 2017; Janurik, Szabó \& Józsa, 2020). 


\section{Miért fontos a hangunk megfelelő állapota és az erre való felkészülés?}

A mindennapok tapasztalata azt mutatja, hogy a minőségi munkához elengedhetetlenül szükséges a jó hangképzés, beéneklés. Egész tanításunkra, nevelésünkre is kihatással lesz, eredményesebbé válhat ettől. Gondoljunk bele, hogy egy testnevelésóra vagy edzés eredményességét mennyire segíti a jó bemelegítés!

„Én már nem tudok énekelni, nincs hangom, elment a hangom” - halljuk sokszor. Ha felsőlégúti megbetegedések következtében megy el valakinek a hangja, az egyébként egészséges ember fátyolos, rekedt, megváltozott (lemélyült) hangja a helytelen hanghasználatra vezethető vissza, éneklése romlik el, mert a hangjára nehezedő terhelés nincs összhangban hangadásának technikájával. A szép hangot rossz irányba befolyásoló tényezők lehetnek még továbbá a kisgyermekkorban hallott kemény, durva beszédmód, közeli hozzátartozó lemélyült torokhangja, zajos környezetben történő beszéd, médiából áramló zenék rossz énekléseinek átvétele, torokból éneklő nevelő, pedagógus, feszültséggel-szorongással teli élet vagy akár a technikai ismeretek nélküli tartós terhelés (Bruckner, 1999).

A gyermekek hangaszalagja rövidebb, vékonyabb, ezért természetesen magasabb hangfekvésbe kívánkozik a hangjuk. Sok gyermeknek már kis korában lemélyül a hangja, mert utánozza a környezetében élők éneklését, vagy az épp adott pedagógust, aki nemfoglalkozik saját hangképzésével. Saját regiszterükben kell őket énekeltetni jól vezetett, csupa játékos hangképzéssel. A gyerekeknél egyébként különbséget kell tenni a botfülü és a morgós között. Bruckner (2019) szerint az igazi botfülű gyermek ritka, az úgynevezett morgós viszont csak zeneileg az éneklésben gyakorlatlan. Ha csak arról lenne szó, hogy saját magunknak ártunk ezzel, lehetne magánügy is (mint például a dohányzás). De itt a gyermekek hangjáról, hangképzéséről is szó van, amelyért felelősséggel tartozunk, s akik önkénytelenül átveszik a pedagógus hangadásmódját. A dohányzás következtében a hurut állandósul, szükül a hangterjedelem, ha erre ráénekel, megváltozik a hangja.

A magyar óvodai és iskolai gyakorlat jelentős szerepet szentel az éneklésnek, ugyanakkor az éneklés iránti motiváció vizsgálata a hazai kutatásokban csak kevés figyelmet kapott. Az ének-zene órák iránti attitűd alakulásában döntő szerepet játszik magának az éneklésnek a kedveltsége, állapítja meg Janurik és Józsa (2018). Vizsgálatukban az iskolai ének-zene órák kedvelésével az éneklés szeretete mutatja a legerősebb kapcsolatot. Ennek ellenére az éneklés iránti közömbösség jellemző az iskolásokra, vizsgálatuk azt is kimutatta, hogy iskolán kívül, otthon sem okoz az éneklés örömet a fiatalok számára. A tanulók ének-zene tanulásához kapcsolódó negatív énképe további nehézséget jelenthet. Az éneklésben való sikertelenség esetén önbizalomhiány alakulhat ki bennük, negatív vélekedéssel, egy idő után elöítélettel állhatnak hozzá egy-egy énekórai tevékenységhez. Mindez a képességfejlesztés jelentőségére is rámutat. Hiszen, ha a gyermekek nem érzik önmagukat 
kompetensnek, nem hisznek abban, hogy képesek megoldani a feladatot, akkor elveszíthetik motiváltságukat (Janurik \& Józsa, 2018).

Asztalos (2015) kutatása szintén azt támasztja alá, hogy a motiváció érdekében szükség van az ének-zene órákon alkalmazott módszerek és eszközök megújulására, élményszerü ének-zene órák tartására, melyben az éneklésnek is szerepe van. Véleménye szerint a kreatív, az új módszertani lehetőségek keresése iránt elkötelezett, megújulni képes pedagógus lehet leginkább csak eredményes e téren.

Azok az egyének, akik önmagukról úgy vélekednek, hogy nincsen „zenei hallásuk" (tone deaf), nem muzikálisként írják le önmagukat és tartózkodnak bármilyen zenei tevékenységtől. Ezt az állapotot állandónak tartják és rendkívül behatároltnak érzik azokat a lehetőségeket, zenei célokat, amelyek teljesíthetőek számukra. Sokan közülük átlagos zenei észlelési és éneklési képességekkel rendelkeznek, azonban sokkal fejlettebb társaikkal hasonlítják össze önmagukat, emiatt nem szívesen énekelnek mások előtt, zenei képességeik aktuális fejlettségére pedig észlelt éneklési képességeik alapján következtetnek (Sloboda, Wise \& Peretz, 2005).

\section{Mit tehet a pedagógus, hogy a hangja ne fáradjon el a tanítási nap végére?}

Forrai Katalin $(2016,2017)$ Ének az óvodában című könyvében olvashatjuk a zenei bemutatás, előadásmód alfejezetben, hogy az óvodában a zenehallgatás elsősorban az egyszólamú élő zene meghallgatását jelenti Az óvónő készüljön fel a dal szép előadására, a színes, ízléses előadás kelt csak figyelmet. Elsődleges élő hangszerünk a saját hangunk.

Az énekhang segítségével a kiművelt halláson van inkább a hangsúly, viszont kevés szó esik a kiművelt hangról. Ahogy a hangszeren megtanítják az adott instrumentum kezelésének technikáját, úgy ahhoz, hogy a ránk bízott énekhangokkal, azok fejlesztésével megfelelően tudjunk foglalkozni, a résztvevők életkori sajátosságaihoz igazodva, először is magunknak kell jó hangképzéssel énekelni. Egyrészt, hogy megfelelő mintát tudjunk adni, másrészt, hogy a pályával járó hangi terheléseket bírjuk, hangunk, esetleges énektechnikánk károsodása nélkül. Ki kell fejleszteni a funkcionális hallásunkat, hogy meg tudjuk különböztetni a jó éneklést a rossz énektechnikától, s hogy meghalljuk, mi okozza a hibát, de ez egy fejlődési folyamat eredménye. Ez már az oktatás, tanítás módja: valamint jó instrukciókat kell tudnunk adni. Egy nyelvtanártól elvárjuk, hogy ne csak szavakat, nyelvtant, az idegen nyelv megértését, írását oktassa, hanem, hogy ő maga is minőségi módon használja a nyelvet mind a helyes kiejtés, mind a nyelvtan, nyelvhelyesség szempontjából. Ugyanez elvárható a gyermekhangokkal foglalkozó pedagógustól, nevelőtől, ha már zenetanításunk éneklésen alapszik.

A gyakorlati hangegészségtan szerint felváltva beszélni, illetve énekelni nagyon megerőltető feladat még a hivatásos énekeseknek is. Tehát javasolha- 
tó, hogy ne a hangunkkal teremtsünk csendet egy zsibongó osztályteremben, hanem például triangulummal, cintányérral addig csilingeljünk, amíg el nem csendesednek, így ezután ismét folytathatjuk a beszédet vagy éneklést - természetes hangon. A kiabálás, emelt hangerővel történő beszéd is árt. Tartós hangtúlerőltetés esetén rögzülhet a funkciózavar, állandó rekedtséggel küszködhetünk. Mindenkor a saját alkati adottságunknak megfelelő helyességgel megoldott hangzóképzéssel beszéljünk tanítás, nevelés közben (Bruckner, 2019).

Fontos megemlíteni a légúti megbetegedéseket, amelyek leggyakrabban náthával kezdődnek. A nátha miatt a belső rezonanciális helyzet megváltozik, másképp halljuk magunkat, mert nazálisabb csengést kap a hang és ezt összekeverjük a rezonanciális érzettel. A tanév végén például ideális lenne kettő-négy hétig teljes hallgatással pihentetni a hangunkat. Vagy amennyiben egy színházi előadást végignevetünk, élénk beszélgetéssel szóval tartjuk a buszvezetőt, osztálykiránduláson a buszon-vonaton hangosan beszélünk, nevetünk, másnap nem találjuk a helyén a hangunkat. Ezért nagyon fontos a bő folyadékbevitel, ne hagyjuk kiszáradni a torkunkat.

\section{Káros-e beéneklés nélkül dalra fakadni?}

Nem. Az ilyesmi ellenállhatatlan érzelmi megnyilvánulás, ami spontán, így kárt nem okoz. Az illető akkor zendít rá, amikor belső indíttatást érez és akkor hagyja abba, amikor ez a vágya kielégült. Viszont a gyermekek és ezáltal mi is egy adott iskolai, óvodai környezet adott helyzetében késztetésre („utasításra”) kell, hogy énekeljünk: külső vagy belső szándék, akarat következtében éneklünk, adott időpontban, egyénileg vagy közösen meghatározott hangmagasságon, egyénileg vagy csoportosan kiválasztott tartalommal.

Ide tartozik a népi és a klasszikus énekes esete: az autentikus népi hangvétel kemény, torokból vezérelt, beszédszerű szövegmondással és teljes átéléssel, de csak szűkebb hangterjedelemben. Azt, hogy ezt lágyítsuk és magasságot, nagyobb hangterjedelmet várjunk el, külön odafigyelést, technikai ismereteket igényel. Tudatosítani kell magunkban a problémát, a két éneklési mód különbségét.

Sokszor előfordul, hogy beéneklés ugyan van, de nem az adott izomcsoportra célzott fejlesztő hatású mozgások. Például oda-vissza skáláztatunk mindenfajta hangképzési instrukció nélkül, ráadásul intonációs feladatot is adunk közben. Ezekkel a zsonglőrködésekkel azt érjük el, hogy máris feszülten figyelni kell a feladatra.

\section{Beszéd és ének}

Az emberi kommunikáció elsősorban (de nem csak) a vokális viselkedés két különálló, mégis összefüggő formáján keresztül zajlik: beszéd és ének, melyeknek közös az anatómiai és élettani szerkezete. Minden beszélt nyelvnek 
megvannak a saját dallamkontúr-elemei (prozódia), amelyek lehetővé teszik, hogy jobban felismerjük a vokális hangok mintázatait, és értelmezzük ezeket, amikor megtanulunk beszélni. Ezek kombinációja, mint az éneklés is, agyi tevékenység. Az agy a zene, beszéd, vizuális, motoros és érzelmi rendszereinek integrációját végzi ezáltal (Thompson, Schellenberg \& Husain, 2004).

Csecsemő- és kisgyermeknevelők, akik nem a gyerekeket énekeltetik, hanem nekik énekelnek, mondókáznak, miként az anyukák is, az anyanyelvet sajátíttatják, mélyítik el. De hogyan? Gondosan, figyelve minden szó, hang, mondat megfelelő ejtésére? Ahogy Kodály mondja, sajátos hangzására? Kihasználva a bennük rejtőző lehetőségeket a nyelvművelésre, vagy csak nagyjából, felületesen, kötelességből, azaz zeneietlenül? Hiszen ezek „csak” gyermekdalok, néhány hang, ritmus kombinációi!

Földes Imre egy előadásában kimutatta, hogy a legegyszerübb gyermekdalok, például a Süss fel, nap, csíráikban a legnagyobb zeneművek formai jellemzőit hordozzák! Igazából azért kell, hogy énekeljük ezeket, mert szeretetünket kimutatandó - valami szépet akarunk nekik mutatni, adni; valójában folyamatos mintát szolgáltatunk. Az idegen nyelvek oktatásánál is rájöttek, hogy a memorizálás sokkal könnyebb és tartósabb, ha énekelve történik, ezt láthatjuk a tankönyvekben is. Az agykutatók megfigyelései is összevágnak ezekkel, merthogy a szöveges énekléssel a két félteke munkája összekapcsolódik, főleg, ha még az érzelmeket is hozzátesszük. Ajánlom Hámori József $A z$ emberi agy aszimmetriái (2001) vagy egyéb művei áttekintését, vagy éppen Freund Tamás és Csépe Valéria előadásait. Óvodában már énekelni is tanítjuk a gyerekeket, ahol - kedvüket nem elvéve - muszáj jó példával javítani, helyesbíteni, azaz nevelni. Ez azért is nagyon fontos, mert a kisgyermekek - a környezetükben lévő felnőttek számára időnként érthetetlenül - nagyon szeretik az ismétlést, és számtalanszor éneklik azokat a dalokat, amelyek a szívükhöz közel állnak. Pedig, főleg, ha óvatosan, de segítjük a megfelelő mintával, a sok ismétléssel legfontosabb nyelvi tevékenységeket végzik! Nem is gondolunk bele, hogy mennyit lehet indirekt módon használni a megfelelő hangsúlyozás, hosszú és rövid hangzók, szótagok életszerü kiejtésével.

Az „iskolásnak” nevezett éneklésmóddal - a dal sematikus, csak ritmusra és dallamhangokra korlátozott előadásával, figyelmen kívül hagyva a hangsúlyozást, karaktert - a zenének a puszta szövegen túlmutató hatása is elmarad. Iskolai órákon ezért is nagyon fontos, hogy a készség-, képességfejlesztést követően, amikor kiemelünk motívumokat, ritmusukkal is foglalkozzunk, csak úgy szabad továbbmenni, ha a dalba visszahelyezve, életszerủen, kifejezően - azaz megfelelő karakterrel, jó szövegejtéssel - elénekeljük az egészet, ha játékdal, akkor lehetőleg játékával együtt. Nehezebb dalok tanításánál is elengedhetetlen a nehezebb részek kijavítását követően az élményszerü éneklés gyakorlása! Mitől jó a szövegejtés? Természetesen túlzásoktól mentesen, a szótagok hosszúságának megfelelő, azaz beszédszerü kiigazítása. Régen az emberek azért énekeltek, mert pillanatnyi hangulatuk 
vagy az élethelyzet azt igényelte. Aki ismeri Forrai Katalin műveit, bemutatóit, előadásait, tapasztalhatta, hogy nagyon sokszor utalt erre, illetve mutatta is, hogyan kell, hogyan nem szabad énekelni.

Mindez egyébként az énekkari munkának is egyik sarkalatos pontja, akár anyanyelven, akár idegen nyelven éneklünk, a mű karakteréhez így juthatunk közelebb.

Sok egyéb nyelvtani jelenséget is megtaníthatunk, mélyíthetünk a müvek szövegének kimondásával, a helyes hangsúlyozással, például a jelzők (és nem a jelzett szó) vagy a tagadószó hangsúlyos voltával, vagy éppen az összetett szavakkal. Ezek attól összetett szavak, hogy a második rész nem kap hangsúlyt, illetve kisebb, úgynevezett mellékhangsúlyt kap. Amennyiben igen, az akár egészen mást is jelenthet: ez az úgynevezett logikai hangsúly. Eszembe jutott egy öszi híradó, ahol a sporthírekben megemlítették, hogy valamelyik sportágban megválasztották „az újszövetségi kapitányt”! Szegény ószövetségiek! Az állami fenntartású iskolákban is kapnak a gyerekek rendszeresen „egyházi feladatot”! Az ilyen típusú nyelvi játékosságokat a nyelvi bravúrjaikról ismert költőink is kihasználják, gondoljunk Weöres Sándorra, Romhányi Józsefre vagy - a kortársak közül - éppen Lackfi Jánosra.

A rossz értelemben vett ritmizálás mellett egy másik gyakori jelenség, a „legato" helytelen használata, amely szintén problémák kiváltóója. Sok torzulást okozhat. Van, aki megfelelő éneklési gyakorlat hiányában nem mer levegőt venni a sorok végén, mert fél attól, hogy nem talál vissza a levegövétel után a jó hangra. Ennél rosszabb, amikor úgy értelmezzük a legato-t, hogy ezen a címen összemossuk a szavakat, sokszor az esedékes hangsúlyok kihagyásával. Az ilyen jelenségeket a gyerekek is sokszor észreveszik. A karácsonyi dalok között a „kis Jézus” kifejezések környékén is sokszor a Szent Család pelenkázási szokásai kerülhetnek előtérbe, ha az „imádjukakisjézuskát” módon legátózunk. Sok példa említhető ezekre („mité repedő kebel e romok ormán..., vagy az István, a királyban az új családnév: Árpádné Pehely; az Abigél egyik dalában a zenei hangsúly úgy jön ki, hogy „fényt kapaszellem” lesz). Ėrdemes vigyázni, s a nem szerencsés prozódiát kis hangsúlyozás-korrekcióval helyre tenni, mint a népdalok többedik versszakai esetében tették és teszik a jó énekesek.

Lehet, sőt kell szójátékokra érzékennyé tenni a gyerekeket, ez is növeli a nyelvi finomságokra való fogékonyságot. Ezért kell saját magunkra is figyelni, s tanításkor énekórán, vagy kóruspróbán felhívni a figyelmet, hogy ha úgy ejtik, az torzulást okozhat, tehát - nem modorosan - kis tagolást beiktatva kell énekelni. Vicces - és ezáltal motiváló - hatást eredményezhet az a feladat, mikor azonos ritmikájú dalok sorainak szövegét felcseréljük a másikéval.

Sok nyelvet beszélő tudósok szerint a magyar a legszebb, legdallamosabb öt nyelv között szerepel. Mai modern világunkban kezd kiveszni az igény a szép kiejtés iránt, a helyesírás pedig a chat-nyelv miatt is romlik. Talán még nem késő a felnövő generációval megéreztetni és visszaadni a szép beszéd örömét! Ha - akár a vicces feladatokon keresztüli motivációval - 10 éves ko- 
rukig alaposan beléjük neveljük a helyes beszédet, nyelvi önkifejezést, talán kevesebb kopik belőle a későbbiek során. A mostani kor arra késztet mindenkit, hogy szinte iparszerüen, folyamatosan „nyomkodjuk” telefonjainkat, kevesebbet és sok esetben egyre igénytelenebbül beszéljünk.

Ne engedjük, hogy nyelvünk szépsége ellaposodjon, sajátos íze-zamata kikopjon. Frissítsük fel ismereteinket és próbáljunk minél helyesebben, igényesebben beszélni és erre tanítani gyermekeinket.

\section{Összegzés}

A manapság divatos kifejezést, a Life Long Learning-et régebben úgy mondtuk, hogy jó pap holtig tanul... A kellő énektechnikai tudás birtokában azonban megőrizhető a hang egészsége, különösen, ha élethosszig tartó tanulás követi. A gége porcos szerv, nem öregszik, tehát a kor elörehaladtával is lehet hangot képezni, a hang nem a korral megy el, hanem a helytelen hanghasználat miatt. De azért tudjuk, hogy az idősebbeknél, akik sok tapasztalattal rendelkeznek, az éneklés már nem jár egyenes arányosságban a lelkesedéssel. Szűkülnek a lehetőségek, nem bír annyit a szervezet. Ha a magasságot korábban nem technikai tudással valósította meg, hanem erőből, mert a fiatalság rugalmassága lehetővé tette, az ma már meg sem szólal (vagy hallgathatatlan minőségben) és a mély hangok sem. Itt már egyénre szabottan kellene munkát végezni. Több zöngegyakorlatot érdemes alkalmazni. Először mindig a közép-magas zönge jó helyét kell meghatározni, majd fokozatosan lejjebb. Belülről ez már alig hallatszik. S ne feledjük, ami az egyszerủ hallgató számára gyönyörüséges, élvezetes élmény, az a tanult énekes számára számos technikai megoldás, belső mozdulatok, érzetek meghallása.

Saját magunk fejlődése, a tanításunk tanulása, ami manapság különösen fontos, hogy értéket és élményt képviseljen a jó pedagógussá válás útján. A tiszta éneklést csak jó hangképzéssel lehet elérni, az intonációs probléma legtöbbször hangképzési hibára vezethető vissza. Ha mi magunk nem tudunk megfelelő magasságon énekelni, akkor a gyermekek számára nem lesz élvezet az óra, foglalkozás. Ehhez természetesen a pedagógus önképzése, egészséges hangja is elengedhetetlen, mivel gyerekek között a beszéd, az ének igen megterhelö.

A végső cél az, hogy a zenélés öröme létrejöjjön, s ennek az óvodában, iskolában, a kórusban a szép hang (azaz jó éneklés) az eszköze. A szép hangot, a jó éneklést viszont a jó hangképzéssel tudjuk elővarázsolni. Egy ország énekkultúrájának fokmérője, hogy a köznép hogyan énekel, énekel-e egyáltalán.

„Mondd meg nekem, mit dalolsz, megmondom, ki vagy. A bennünk továbbrezgő dallamok és foszlányaik olyat vallanak felőlünk, amit semmi lélekelemzés nem hoz felszínre. Bevilágítanak a lélek rejtett zugaiba, ahova másképp nem férkőzhetünk." (Bónis, 1974) 


\section{Irodalom}

Altorjay, T (2019). Klasszikus énekesi hangképzés empirikus kutatása, az orr és melléküregei bekapcsolhatóságának vizsgálatára. Doktori disszertáció. https:// doi.org/10.14232/phd.10129

Asztalos, A. (2015). Az éneklési képességek fejlődésének vizsgálata. Parlando, 56(5). https://www.parlando.hu/2015/2015-5/AsztalosA.pdf (2020. 12. 20.)

Berkowska, M. \& Dalla Bella, S. (2009). Acquired and congenital disorders of sung performance: A review. Advances in Cognitive Psychology. 5(5), 69-83. https:// doi.org/10.2478/v10053-008-0068-2

Bónis, F. (1974, Ed.). Kodály Zoltán: Visszatekintés. Összegyüjtött írások, beszédek, nyilatkozatok. Zenemükiadó Vállalat.

Bruckner, A. (1999). Énekelni jó(l)! Kodály Intézet.

Bruckner, A. (2019). Egy kis technika. Zeneakadémia Kodály Intézet.

Erős, I. (1993). Zenei alapképesség. A zenei alapképesség fejlödése 3-23 éves korban. Akadémiai Kiadó.

Forrai, K. (2016, 2017). Ének az óvodában. Móra Könyvkiadó. https://doi. org/10.30716/RSZ/2017/1/24

Janurik, M. \& Józsa, K. (2013). A zenei képességek fejlődése 4 és 8 éves kor között. Magyar Pedagógia, 113(2), 75-99.

Janurik, M. \& Józsa, K. (2018). Az iskolai zenetanulás iránti motivációt alakító néhány tényező. Gyermeknevelés Tudományos Folyóirat, 6(2), 5-17. https://doi. org/10.31074/gyn20182517

Janurik, M., Szabó, N. \& Józsa, K. (2020). A zenei énkép jellemzői és összefüggése a zenei képességekkel hetedik osztályosok körében. Magyar Pedagógia, 120(2), 171-200. https://doi.org/10.17670/MPed.2020.2.171

Peretz, I. \& Zatorre, R. J. (2005). Brain organization for music processing. Annual Review of Psychology, 56, 89-114. https://doi.org/10.1146/annurev.psych.56.091103.070225

Pukánszky, B. \& Németh, A. (1996). Neveléstörténet. Nemzeti Tankönyvkiadó.

Sloboda, J. A., Wise, K. J., \& Peretz, I. (2005). Quantifying tone deafness in the general population. Annals of the New York Academy of Sciences, 1060(1), 255-261. https://doi.org/10.1196/annals.1360.018

Spychiger, M. (2017). From musical experience to musical identity. In Macdonald, R., Hargreaves, D. J. \& Miell, D. (Eds.), Handbook of musical identities (pp. 267-287). Oxford University Press. https://doi.org/10.1093/acprof:oso/9780199679485.003.0015

Thompson, W. F., Schellenberg, E. G. \& Husain, G. (2004). Decoding Speech Prosody Do Music Lessons Help? https://www.researchgate.net/publication/8646949_ Decoding_Speech_Prosody_Do_Music_Lessons_Help (2020.12.13.)

Turmezeyné Heller, E. \& Balogh, L. (2009). Zenei tehetséggondozás és képességfejlesztés. Kocka Kör Tehetséggondozó Kulturális Egyesület. 
Welch, G. F. (1997). The Developing Voice. In Thurman, L. \& Welch, G. F. (Eds.), Bodymind and Voice: Foundations of Voice Education (pp. 481-494). National Centre for Voice and Speech. 


\section{Kovács, K. \& Döbrössy, J.}

\section{Vocals and tone formations}

The Music Education Conference 2021 of the Department of Singing and Music of the Eötvös Lorand University Faculty of Primary and Pre-School Education focused on Hungarian music and culture. The two lectures in the subtitles of this paper are related. Both topics are important areas of early childhood education. Setting a good example with correct tone formation and articulation, creating a clear and appropriate text for our mother tongue, and exercises that guide us to the original tone formation and correct singing are crucial for education. The aims of our music education are based on the concept of Zoltán Kodály. The essential element of the Kodály concept is that singing leads most directly to the experience and understanding of music. In our vocal-based music education, the singing approach must be much more prominent. Singing liberates, enriches and gives joy. Technical knowledge provides the means to solve musical tasks. Active music-making, singing and the development of musical skills offer the opportunity for the reception of the content of art, personal development and musical development.

Keywords: early childhood education, singing, voice training, articulation, intonation 